\title{
TAXATION OF FARMERS BY THE INCOME TAX IN SERBIA
}

Goran Milošević ${ }^{1}$, Marija Vuković ${ }^{2}$, Duško Jovanović ${ }^{3}$

*Corresponding author E-mail: bakibane2010@gmail.com

\begin{abstract}
A R T I C L E IN F O
Review Article

Received: 03 March 2018

Accepted: 26 March 2018

doi:10.5937/ekoPolj1802683M

UDC 336.221:338.43(497.11)

Keywords:

farmer, agricultural holding, taxable income, personal income, individual activity.

JEL: Q14, H24

\section{A B S T R A C T}

The tax system must be in accordance with the requirements and interests of the tax authorities, but also with the goals of taxpayers. Fiscal intervention should reflect the taxpayer's fiscal power as well as certain forms of taxation. In that regard, agricultural production activities are also the subject of taxation as they are conducted by a large number of entities who have different financial positions and conditions of production. The holders of agricultural production activities achieve their goals, and thus the economic interests of the country are fulfilled. The government show through various measurements that agriculture is an important economic sector and encourage its growth and development. As an instrument of their economic policy, the government can also use the taxation system for agriculture. Taxation of agriculture leads to the achievement of the economic and fiscal goals of the country as well as non-taxation goals. Tax policy measures can, therefore, either encourage or discourage agricultural production activities.
\end{abstract}

(C) 2018 EA. All rights reserved.

\section{Introduction}

Economic resources: capital, human resources and natural resources are elements of the production process. By their scope and optimization of use, they are both the condition and presumption of the wealth of a country. In a sufficiently long period of time, economic resources will still show the effect of limitation. The limitations of the use of economic resources indicate the limited production possibilities of any economy. The economic selection in the condition of limited resources requires their rational allocation (Popov, 2015) due to the fact that resources can be used in alternative ways.

1 Goran Milošević Ph.D., Full Professor, University of Novi Sad, Faculty of Law, Trg Dositeja Obradovića no. 1, Novi Sad, Serbia, E-mail: g.milosevic@pf.uns.ac.rs

2 Marija Vuković Ph.D., Professor of professional studies, Novi Sad Business School, Vladimira Perića Valtera street no. 4, Novi Sad, Serbia, Phone: +381 648654 109, E-mail: vlahmari@uns.ac.rs

3 Duško Jovanović Ph.D., Associate professor, School of Economics and Management studies, Karadjordjeva street no. 52, Kragujevac, Serbia, Phone: +381 638032 551, E-mail: dule.jovanovic.kg@gmail.com 
The limitation of economic resources, and therefore of natural resources, will lead to their different and specific treatment in the competitive market. Namely, their limitation is a significant component of the price. Through the market mechanism, the pricing policy influences the reduction, i.e. the slowdown in the exploitation of natural resources and the policy of their rational use. In this way, the community tries to preserve or limit the use of non-renewable sources of production through the pricing policy.

Natural resources from the aspect of limitation are relatively different. Some resources are less limited in the process of use than others (Ristić, 2001). A group of natural resources consists of land, water, forests, mineral wealth, air and all organic and non-organic things. They are elements of production characterized by the exploitation of the source, because in nature, in the earth's crust there is a limited amount of these resources. When these natural resources are exhausted, human society will have to use all its knowledge and skills to find other sources of satisfying its needs. Land as a natural resource can be exploited in the production of agricultural crops in an unpredictable term. However, land as a natural resource has limited scope and quality. The limitation of the scope and property over the land give a special quality to this resource. If all the land had the same properties and existed in unlimited quantities and of equal quality, nothing could be charged for its use unless it had particular advantages of its position (Samuelson, 1975). Land as a natural resource is of limited size, which means that it cannot be produced or expanded. Hence, land as a production factor has the fixed supply.

Land can sometimes be "increased" by irrigation, utilization of plants, etc. However, over-exploitation of the soil can have negative consequences that are followed by a reduction in fertility and subsequently a fall in yields of crops. This shows that land is basically the input of production with the fixed size and it cannot be expanded. In contrast to supply, demand for land is a category derived from demand for goods produced on that land as a factor of production (Aničić, Simić, 2017). The entities of the production process use land as a natural resource most often in the process of agricultural production activity. The process of agricultural production activity is complex and demanding. This activity is conducted by a large number of entities who have different financial positions and conditions of production. The projected goal is to achieve production and gain the surplus of products and profit (Piketi, 2015).

Agricultural production activities can be organized in the form of an individual agricultural holding or as an agricultural company (Milošević, Kulić, 2011). Individual agriculture is characterized by a small fragmented estate, production for their own purposes and poor organization. The inappropriate organization of individual agriculture results in the fact that, even in favourable conditions, the farmers are not able to secure a higher profit for themselves through the system of favourable prices of agricultural goods.

\section{Taxation and market equilibrium of farmers}

Through taxation, or subtracting a portion of the taxpayers' payers, the government achieves the fiscal target as well as certain effects on the demand of goods and services on the 
market, change in prices, change in production, financial position of the taxpayers, choice of investment decisions, etc. Within the taxation system of agriculture the government must set the boundary of taxation of this production activity. The excessive burden of agriculture can cause economic inefficiency, decline in production volume and collapse of agricultural production activities. Hence the government must establish a sufficiently flexible system of taxation that will lead to achieving fiscal goals (Kulić, 2000) and defending the interest of the entities involved in the agricultural production activity.

We can analyse the taxation system from the point of view of the effects of imposing the tax on agricultural production activity $\left(\mathrm{Y}_{0}\right)$. According to the scenario, the following is assumed: the perfect performance of the market; optimal scope of agricultural production activities (balance in point B); additional agricultural production activity means that the cost of producing an additional unit exceeds the benefits.

Figure 1. Taxation in agriculture (Y)

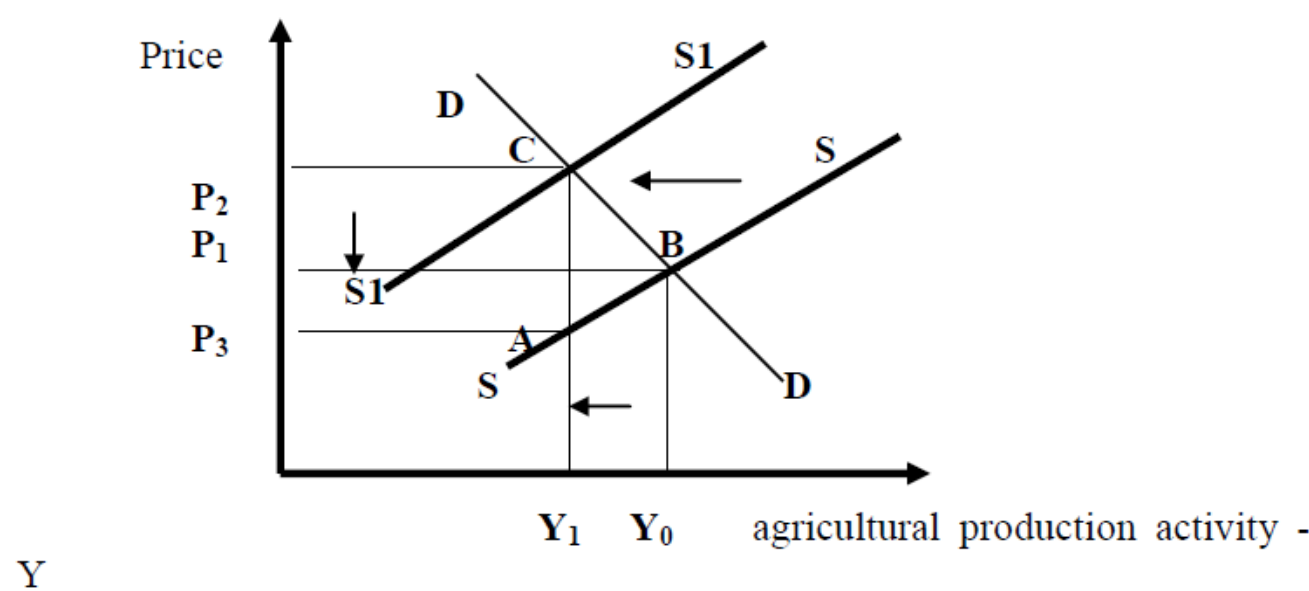

Note: DD - demand curve; SS - supply curve;

Source: Work of authors.

Therefore, the equilibrium is achieved in point $\mathrm{B}$, where the production volume is $\mathrm{Y}_{0}$ and the price is $\mathrm{P}_{1}$. If we introduce a tax (in the $\mathrm{AC}$ value) for each unit of activity produced (Y) in the analysis of the agricultural activity, the equilibrium will be established in point $\mathrm{C}$. Namely, the introduction of the tax would lead to an increase in production costs (Y). The increase in production costs caused by the introduction of tax burden (AC) makes agricultural production entities to raise the price of their product from $\mathrm{P}_{1}$ to $\mathrm{P}_{2}$. The price level of $\mathrm{P}_{2}$ allows the farmer to cover all production costs that include the tax burden (AC) of the given production level. The new $\mathrm{P}_{2}$ price would move of the supply curve upward into a new equilibrium position S1S1. Since the taxpayers are obliged to settle their tax obligation, they do not, therefore, gain the income determined by the level $\mathrm{P}_{2}$, because the tax $(\mathrm{AC})$ is within the market price $\left(\mathrm{P}_{2}\right)$ so they will only have the amount of $\mathrm{P}_{3}$ per unit of production $(\mathrm{Y})$. The equilibrium level of production is also shifted from $\mathrm{Y}_{0}$ to $\mathrm{Y}_{1}$, as the new equilibrium market price is now set at $\mathrm{P}_{2}$ level. 
The tax revenue (Figure 1) is determined by the size of the product, the number of sold product units and the amount of tax (AC). The tax burden is determined in the ABC zone. The effect on farmers due to an increase in prices caused by the introduction of taxes is the decline in production from $\mathrm{Y}_{0}$ to $\mathrm{Y}_{1}$ and the potential loss of economic wealth. From the aspect of agricultural activity this can mean that the state of efficient allocation of resources has shifted to the suboptimal position, so the tax authorities while defining the taxation in agriculture must take into account all the effects of taxation of this production activity.

\section{Income tax system and agriculture}

The system of agricultural production activity is the subject of the interest of economists, agroeconomists, lawyers, businessmen, and everyone else who conducts scientific research into this sector of economy. Some of them attempt to solve the problems of agricultural production as the bearer of the development of the economy, whereas the others start from the standpoint that agricultural products are essentially intended for human consumption, and thus they are the precondition of people's existence so they analyse the prices of agricultural production, i.e. prices of agricultural products and their impact on consumption of the population and economy. There are also those who try to consider the possibilities of raising the level of income in agriculture through a reduction of costs in business operations.

In this area the government show that agriculture is an important economic sector. The government try to achieve their economic goals through their activities (Stiglitz, 2013), without disturbing the market equilibrium established at the macroeconomic level (Raičević et al., 2016). With their instruments, the government encourage the growth and development of agricultural production activity, but sometimes these instruments, if they are not synchronized with other measures and instruments of economic policy, can negatively affect the flows in the field of agricultural production activity. Fiscal policy as part of the economic policy of a national economy produces the tax goals of the country, but also non-taxation goals (Kovačević, Ilić, Damnjanović, 2017). Hence, tax policy measures can either encourage or discourage agricultural production activity. The importance of the issue of taxation of farmers gets more important when we take into account the fact that the number of members and permanent employees of agricultural holdings of Serbia (according to the data for 2013) totals 1.44 million, out of which even 98 percent are the owners of the farm and members of their households (Cvjetković et al., 2015).

Within the tax system of Serbia, taxation of agriculture distinguishes between agricultural holdings and individual agriculture (Milošević, Kulić, 2011). Agricultural legal entities have the same treatment in the taxation as all other legal entities and they are in the system of corporate income tax. Individual farmers are natural persons, and from the aspect of taxation, it means that they are in the system of personal income tax. 
Personal income tax is paid by natural persons, including farmers, who earn income (Individual Income Tax Law - hereinafter IITL). This is a subjective tax that affects the total revenues of a particular taxpayer (Gnjatović, 1999). Revenue is the sum of taxable income generated in the calendar year. Taxable revenue is the difference between the gross taxable revenue generated by the taxpayer and the costs incurred during its generation and preservation. Income tax is obligatory for the following types of income (IITL, article 3): wages and salaries; revenue from self-employment; revenue from copyright, rights related to copyright and industrial property rights; revenue from yield on capital; revenue from real estate; capital gains; and other revenues. These revenues shall be taxable regardless of whether they were received in money or in kind, on the basis of performance or in some other way. A taxpayer is a natural person who is bound to pay taxes. The taxpayer of income tax is a resident of the Republic of Serbia, for income earned in the territory of the Republic of Serbia and in another country. The resident of the Republic of Serbia is any individual whose residence or centre of business and vital interests is in the territory of the Republic of Serbia and who resides in the territory of the Republic of Serbia for 183 or more days, continuously or with breaks, over a period of 12 months beginning or ending in the respective fiscal year (IITL, article 7). A taxpayer of personal income tax is also any individual who is not a resident (non-resident) on the revenue earned in the territory of the Republic of Serbia.

Natural persons involved in an agricultural production activity taxed by the personal income tax system are obliged, in accordance with the law, to determine and pay the tax liability for all forms of taxable revenue generated during the calendar year. These are the following forms of revenue: revenue from self-employment, salaries and other forms of income from agriculture as defined by the personal income tax. In accordance with the law, the revenue from agricultural production activities is considered the taxable annual income.

\section{Tax on revenue from self-employment}

Revenue from self-employment is the income derived from conducting economic activities, including agriculture and forestry, provision of professional and other intellectual services, and income from other activities, provided that the income is not paid according to the law on a different basis. Taxable revenue from self-employment is taxable profit (Raičević, Radičić, 2008). Taxable profit is determined in the tax balance by adjusting the income of the taxpayer (Popović, 1997) stated in the income statement, which is composed in accordance with the accounting regulations if the entrepreneur is entitled to have double entry bookkeeping, or in accordance with the regulation issued by the Minister in charge of affairs finance if an entrepreneur keeps single-entry bookkeeping. The rate of income tax on self-employment is $10 \%$.

A taxpayer is a natural person who generates income from self-employment if the tax is not paid on the other basis according to the law, and any other natural person (entrepreneur) who is a taxpayer of value added tax in accordance with the law on the value added tax. A taxpayer of income tax on self-employed activities based on income from agriculture 
and forestry is a natural person - holder of a family agricultural holding, which kept in the register of agricultural holdings, in accordance with the regulations related to this area (IITL, article 32, paragraph 2) and who keeps financial records in accordance with the law (IITL, Article 43, paragraph 2). This leads to the two cumulative conditions, which the natural person, who is the holder of the family agricultural holding, must fulfil in order to be registered in the register of agricultural holdings and have the status of entrepreneur. These conditions are as follows: (1) the holder is registered in the register of agricultural holdings and (2) the holder keeps business and financial documents. If the natural person, the holder of the family agricultural holdings, does not fulfil the abovementioned conditions, they shall not have the status of an entrepreneur (Announcement regarding the taxation of registered agricultural holdings, 2014).

The natural person who receives income from agriculture obtains the status of entrepreneur and has the obligation to keep financial records (The Decision of the Ministry of Finance of the Republic of Serbia, 2013):

by law - if a natural person is a taxpayer of value added tax in accordance with the Law on the value added tax. According to the Law on value added tax, the farmer whose total turnover of goods and services in the previous 12 months does not exceed the amount of RSD 8,000,000 does not charge the value added tax for the executed turnover of goods and services, has no right to show the value added tax in the accounts and has no right to the deduction of the previous tax and is not obliged to keep the records prescribed by law (Law on value-added tax - hereinafter $L V A T$, article 34, paragraph 5).

at its own discretion - if the holder of an agricultural holding registered in the register of agricultural holdings has decided to have the status of an entrepreneur. This decision is done by submitting a tax return to the competent tax authority (LVAT, article 34, paragraph 6, PPDG-1 Form). A farmer may decide to pay value added tax by filing a registration application prescribed in accordance with the law to the competent tax authority, and then they acquire the rights and obligations which the taxpayer of value added tax has by law. In case that the farmer decides to pay value added tax; this obligation will be in effect at least two years. Upon expiry of the obligation, the taxpayer (the farmer) may submit a request for termination of the obligation to pay the value added tax to the competent tax authority.

Therefore, the owners of registered agricultural holdings are taxpayers of personal income tax if they keep financial records and have the status of entrepreneur, or if their annual income of agricultural holdings exceeds RSD 8,000,000 or if they decide to submit a tax return and thus acquire the status of entrepreneur.

The natural person who generates income from agriculture, and does not have the status of entrepreneur, has no obligation to keep business and financial records. This means that a natural person who generates income by performing activities of agriculture and forestry (IITL, article 85, paragraph 1, item 14), and a registered agricultural holding that does not have the status of entrepreneur, is not obliged to keep financial records 
and is not obliged to pay personal income tax. The above-mentioned category of natural persons is not a taxpayer from the aspect of personal income tax, but is obliged to pay contributions for pension insurance and healthcare insurance in accordance with the law regulating the system of compulsory pension insurance and healthcare insurance, provided that it has an application for insurance on the basis of performing agricultural production activity with the competent fund.

Bearing all this in mind, it is clear that the largest number of farmers in the Republic of Serbia will not be obliged to pay personal income tax (Cvjetković et al., 2015). In this way, starting from the economic environment, the state of agricultural production and the economic strength of the holders of agricultural production activity, the Serbian tax authorities try to encourage small entities of agricultural production activity through the taxation system. However, this decision violates the principle of equality, which means that everyone is bound to pay taxes in accordance with their tax force. Certain subjects of agricultural production are favoured in that way because a significant portion of tax sources remains outside the taxation system.

\section{Adjustment of revenues and expenditures and tax return and tax balance submission}

Taxation of income from self-employment requires the determination of taxable income. Taxable income from farmers' self-employment is taxable profit. Taxable profit is determined in the tax balance by adjusting the profit shown in the income statement, prepared in accordance with the accounting regulations if the entrepreneur has doubleentry bookkeeping, or in accordance with the regulation issued by the Minister of Finance if the entrepreneur is entitled to single-entry bookkeeping (Milošević, 2013). The entrepreneur (the farmer) keeps the financial records in accordance with the law and is obliged to submit the tax return and the tax balance to the competent tax authority no later than March 15 in the year following the year for which the tax is determined. An entrepreneur, who ceases to perform self-employed activity during the year, is obliged to submit a tax return for the determination of the tax within 30 days from the day of termination. The entrepreneur who keeps the financial records is obliged to state in the tax return the amount of the calculated and paid tax in the tax period up to the day of the interruption or the termination of self-employed activity. They are also required to submit a tax balance along with the tax return (Milojević et al. 2015). An entrepreneur who ceases to have the status of a taxpayer of value added tax in accordance with the law shall also submit the tax return within 15 days from the day of receipt of the decision of the competent tax authority confirming the removal from the VAT registration. Entrepreneur who begin self-employed activity during the year are obliged to submit a tax return in which they will provide an estimate of income and expenses, or an estimate of turnover until the end of the first fiscal year as well as an assessment of the monthly tax advance, i.e. the determination to pay personal income within 15 days from the date of registration in the registry of the competent authority, or from the day of commencement of activity (IITL, article 94). 
The adjustment of revenues and expenditures, determination of capital gains and losses and tax treatment of losses from previous years are recorded in the tax balance of the entrepreneur in accordance with the relevant provisions of the law on corporate income tax, unless otherwise provided by law. When adjusting the revenues, the taxpayer will have the right for:

Interest - in the case of a claim from the debtor with the status of a related party or a loan that the taxpayer gives to the debtor with the status of a related party. Persons related to the entrepreneur, in addition to natural and legal persons that have this property according to the relevant provisions of the law on corporate income tax, are also: members of the taxpayer's family; brothers and sisters of taxpayers; parents of the spouse and stepchildren. The interest rate belonging to income in the tax balance cannot be less than the one which would be achieved on the market that it was possible to contract such claims, that is to say, to approve a loan in the accounting period. The difference between market interest rate and accrued interest rate for the between related parties is calculated as taxable profit (IITL, article 37, paragraph 2 and 3).

Outflows taken by an entrepreneur from the business property for private purposes is treated as the business income. The investment of non-monetary assets is estimated at a comparable market value in accordance with the principle of continuity (IITL, article $37 \mathrm{~b}$, paragraph 1).

When adjusting the expenditures, the taxpayer will have the right for:

The depreciation of fixed assets that the entrepreneur disclosed in their financial statements in the amount and in the manner determined by the law on the corporate income tax and other related legal acts (IITL, article $35 \mathrm{a})$.

Interest - in the case of a debt to a creditor with the status of a related party or a loan taken by the debtor from a creditor with the status of a related party. The interest recognized as expenses in the tax balance cannot be higher than the one that could be taken as a loan in the accounting period (IITL, article 37, paragraph 1).

Salaries paid by entrepreneurs; costs of business trip up to the amount determined by law; paid contributions for personal compulsory social insurance based on selfemployment if the entrepreneur did not decide to get a salary (IITL, article 37a).

The investment of personal assets in business property, apart from investments in fixed assets, has the treatment of the business expense of the entrepreneur (IITL, article $37 \mathrm{~b})$.

Tax incentives based on investments in fixed assets in their own registered business and on the basis of investments in accordance with the regulations related to the stimulation of investments in the economy of the Republic. Tax incentives are recognized to entrepreneurs under the conditions and in the manner they are recognized to legal entities under the law on corporate income tax (IITL, article 39). 


\section{Flat tax rate}

The right to flat rate taxation is given to an entrepreneur who, regarding the circumstances, is not able to keep financial reports or this procedure leads to a more difficult performance of their business operations. The entrepreneur (farmer) who earns income by performing independent activities from agriculture and forestry has the status of entrepreneur (registered as an agricultural holding) only if they fulfil two cumulative conditions: (1) they are in the register of agricultural holdings and (2) they keep financial records. Taxation policy clearly indicates that only the natural person may have the status of entrepreneur - the bearer of the family agricultural holding who keeps financial records. The farmers who do not keep financial records will not have the status of entrepreneur so they are not entitled to the flat rate tax. This means that when taxing farmers who generate income from self-employment, the flat rate tax is not applied.

\section{Income tax}

An entrepreneur, and thus a natural person being involved in an agricultural production activity in the status of an entrepreneur, who pays the tax on the actual income from selfemployment activity may opt for the payment of personal earnings. The entrepreneur who opts for the payment of personal earnings is required to submit a written notice to the competent tax authority about their decision to have the payment of personal earnings. The notice shall be submitted no later than December 15 of the current year for the period starting from January 1 of the following year. The entrepreneur who decides to have personal earnings cannot change the decision during the tax period (Milošević, Kulić, 2015). If the entrepreneur decides to stop paying personal earnings, they will be obliged to submit a written notice to the competent tax authority by December 15 of the current year. In case that the entrepreneur decides to stop paying personal earnings and informs the competent tax authority about this will not be obliged to pay the personal earnings starting from January 1 of the following the year (IITL, article 33a).

Personal earnings are considered to be the amount of money that the entrepreneur pays and writes down in the financial records as their monthly personal income plus the corresponding payroll obligations. The salary is considered personal earnings of the entrepreneur determined in accordance with the law (IITL, article 13, paragraph 3). The personal earnings of entrepreneurs, from the perspective of the taxation, consists of the premiums of all forms of voluntary insurance as well as the pension contribution to the voluntary pension fund which are paid by the employer for employees - insured persons involved in voluntary insurance, or for employees - members of the voluntary pension fund in accordance with the law on voluntary insurance, i.e. voluntary pension funds and pension plans (IITL, article 14b, paragraph 1). Exceptionally, the following are not considered the earnings (IITL, article 14b, paragraph 2):

the premium paid by the employer to all employees in the collective insurance against consequences of an accident, including insurance against injuries at work and occupational diseases and collective insurance in case of serious illness and surgical interventions; 
the premium of the voluntary health insurance, or pension contribution to the voluntary pension fund, paid by the employer to employees - insured persons, or members of the voluntary pension fund, in accordance with special regulations related to these areas, up to the amount that has been exempted from payment of contributions in accordance with the law on contributions for compulsory social insurance.

A taxpayer is a natural person who has earnings. The base of the tax on salaries and wages makes up the paid or earned earnings, reduced by the legally determined nontaxable amount. According to the current legal provisions, the amount of reduction is the amount of RSD 11,790 per month for a full-time employee. The income is taxed at a rate of $10 \%$. In the taxation system, tax incentives are provided for entrepreneurs who employ a new person in the form of the right to refund of a part of the paid tax on earnings for a newly employed person. A newly employed person is a person with whom the employer has concluded a contract of employment in accordance with the law on labour relations, and who is registered for the compulsory social insurance at the Central Registry of Compulsory Social Insurance and who, prior to the employment was registered with the National Employment Service for at least six months without interruption, and a person considered a trainee for at least three months. A newly employed person is not a person who was employed by the employer who is a related person to the new employer. The refund of the paid tax is performed in accordance with the law on the tax procedure and the tax administration, within 15 days from the day of submitting the request for return to the competent tax authority.

\section{Taxation of revenues from other sources}

In the system of personal income tax, other revenues are considered as: revenues that the taxpayer incurs with the leasing of equipment, means of transport and other movables, gains from gambling, income from insuring other persons, income of athletes and sports experts, and other income, except those that are specially excluded by this Law (IITL, Article 81). Other revenues, in the sense of the law, are also other forms of revenues of a natural person, who are not taxable on a different basis in accordance with the income tax. From the aspect of our labour, other forms of revenues of a natural person which are taxed by personal income tax (IITL, article 85) are as follows: income from the sale of agricultural and forest products and services, growing and selling mushrooms, bees and snails.

Taxable income gained by a natural person from the sale of agricultural and forest products and services, growing and selling mushrooms, bees and snails, makes up the gross income reduced by a standardized cost of 90\% (IITL, Article 85, Paragraph 4). A taxpayer is a natural person who achieves these revenues.

Exceptionally, revenues from the sale of agricultural and forest products and services, as well as growing and selling mushrooms, bees and snails gained by natural persons are not taxed: bearers of agricultural holdings who pay the compulsory social insurance contributions according to the decision as the insured persons on the basis of agricultural production activity in accordance with the law on contributions for compulsory social 
insurance; beneficiaries of agricultural pensions. (IITL, article 85, paragraph 12). The subject exclusion does not apply to the following natural persons: members of the family farm and farmers who are not insured on the basis of agricultural activity, and who have income from the sale of agricultural and forest products and services, as well as growing and selling mushrooms, bees and snails, so they are tax payers in this regard. The rate of tax on other revenues is $20 \%$.

\section{Annual income tax}

Annual income tax must be paid according to the decision of the competent tax authority on the income earned in the calendar year in line with the law. The annual income tax is paid by natural persons who in the calendar year earned income above triple amount of the average annual salary per employee paid in the Republic in the year for which the tax is determined, according to the data of the state authority responsible for statistics (IITL, article 87 , paragraph 1): residents for income earned on the territory of the Republic and in another state; non-residents for income earned on the territory of the Republic.

Income that is subject to taxation is considered an annual sum (IITL, article 87, paragraph 2): earnings; taxable income from self-employment; taxable income from copyright and related rights and industrial property rights; taxable income from immovable property; taxable income from leasing movable items; taxable income of athletes and sports professionals; taxable other income; income gained and taxed in another country for residents of the Republic of Serbia. Wages and taxable income are reduced for taxes and contributions for compulsory social insurance paid in the Republic of Serbia at the expense of the person who earned income or taxable income, and taxable income is reduced for the tax paid on such income in the Republic. For entrepreneurs who have chosen personal earnings, earnings are deducted for taxes and contributions for compulsory social insurance paid in the Republic to the burden of the entrepreneur who has chosen to have personal earnings, and the taxable income obtained from a self-employment activity is reduced by the tax paid on such income in Republic. Income taxation is reduced for a tax paid in another country. Income tax is increased by the amount that, in the calendar year for which the annual tax is determined, is payable to the payer on the basis of the return of the compulsory social insurance contribution in accordance with the law on contributions for compulsory social insurance. It means that a natural person who earns income by performing activities of agriculture and forestry as well as registered agricultural holdings which in the calendar year earn income higher than the triple amount of average annual salary per employee paid to the Republic in the year for which the tax is determined, according to the data of the state authority in charge of statistics, is the taxpayer of the annual income tax. The taxpayer of the annual income tax is obliged to file a tax return with the accurate data to the competent tax authority at the expiration of that calendar year and no later than 15 May of the following year.

The basis of the annual income tax is the taxable income, which is the difference between income for taxation and personal deductions (IITL, article 88): for the taxpayer it is $40 \%$ of the average annual salary per employee paid in the Republic in the year 
for which the tax is determined, according to the data of the state authority in charge of statistics; for the dependent family member it is $15 \%$ of the average annual salary per employee paid in the Republic in the year for which the tax is determined, according to the data of the state authority in charge of statistics, per member. The total amount of personal deductions cannot exceed $50 \%$ of the taxable income. If two or more family members are subject to the annual income tax, deduction for dependent family members can only be made by one taxpayer. Annual income tax is paid for the basis at the following rates (IITL, article 89): on the amount up to six times of the average annual salary - $10 \%$; to the amount exceeding six times the average annual salary - $10 \%$ on the amount up to six times the average annual salary, plus $15 \%$ on the amount over six times the average annual salary.

\section{Conclusion}

The fiscal target of the government is not only tax revenues from which they will finance public needs, but also the achievement of certain effects within the national and international economy. If the government violates the optimal allocation of economic resources by the measures of taxation, this may lead to economic inefficiency, distortion of the market equilibrium and the effect of tax resistance in the form of the so-called "evading the tax zone".

The introduction of taxes, i.e. the growth of the tax burden on agriculture, will increase the costs of this activity. The increase in costs caused by the introduction of tax burden leads to a rise in the price level of agricultural products. The new equilibrium price of the supply of agricultural products will further disturb the balance in other markets of goods and services.

The effect of the price increase of agricultural products, caused by the introduction of taxes, is the decline in production, but also the potential loss of economic wealth of farmers. From the aspect of agricultural activity this can mean that the state of efficient allocation of resources has shifted to a suboptimal position and tax authorities while defining the taxation on agriculture must take into account all the effects of taxation of this activity.

Agricultural production activity from the aspect of the Serbian economy is a condition and basis of growth. Hence the government must establish a sufficiently flexible system of taxation that will mean the achievement of fiscal goals, but also the achievement of the interest of the subjects of the agricultural activity. The excessive burden of agriculture can cause economic inefficiency, decline in production volume, collapse of agricultural production activity, etc.

\section{Conflict of interests}

The authors declare no conflict of interest. 


\section{References}

1. Aničić, A. \& Simić, M. (2017). Tobin tax in European Union. Oditor, 3(2), 100106. [in Serbian: Аничић, А., \& Симић, М. (2017), Тобинов порез у ЕУ].

2. Gnjatović D. (1999). Finance and Financial Law. Policy Academy, Belgrade. ISBN: 86-7020-059-7. [in Serbian: Гњатовић, Д. (1999), Финансије и финансијско право].

3. Kovačević, M., Ilić, J. \& Damnjanović, R. (2017). Evolution of income tax in Serbia. Oditor, 3(1), 7-22. [in Serbian: Ковачевић, М., Илић, J. \& Дамњановић, Р. (2017), Еволуција пореза на доходак у Србији].

4. Kulić M. (2010). Public finance. University Megatrend, Belgrade. ISBN: 97886-7747-415-7. [in Serbian: Кулић, М. (2010), Јавне финансије].

5. Milojević, I., Zekić, M. \& Gobeljić, Z. (2015). Tax balance in agribusiness as a type of special balance, Economics of Agriculture, 62(3), 767-780. Belgrade. UDC: 332.053:336.226.14.

6. Milošević, G. (2013). Theory and Practice of Financial Law. Crime and Policy Academy, Belgrade. ISBN: 978-86-7020-196-5. [in Serbian: Милошевић, Г. (2013), Теорија и пракса финансијског права].

7. Milošević, G. \& Kulić, M. (2015). Tax Law. Faculty of Law, Novi Sad. [in Serbian: Милошевић, Г. \& Кулић, М. (2015), Пореско право].

8. Milošević, G. \& Kulić, M. (2011). The theoretical basis and practical experience of tax shifting the emphasis on agriculture, Economics of Agriculture, 58(2), 281-298. Belgrade. [in Serbian: Милошевић, Г. \& Кулић, М. (2011), Теоријске основе и практична искуства преваљивања пореза са освртом на пољопривреду].

9. Piketi, T. (2015). Capital in the 21st century. Academic book, Novi Sad. ISBN: 9788662630759. [in Serbian: Пикети, Т. (2015), Капитал у 21 веку].

10. Popov, Đ. (2015). The growth of foreign investments in Serbia - the law and what else? Proceedings of Novi Sad Faculty of Law, 2, 401-416. [in Serbian: Попов, Ђ. (2015), Раст страних инвестиција у Србији - закон и шта још?].

11. Popović, D. (1997). Tax Science and Tax Law. Savremena administracija, Beograd. ISBN: 8631103284. [in Serbian: Поповић, Д. (1997), Наука о порезима и пореско право].

12. Raičević, B., Ignjatijević, S. \& Milojević, I. (2016). Financial analysis of foreign direct investment of economic growth of developing countries. Economics of agriculture, 63(2), 649-663, UDC: 330.322.54:502.131.

13. Raičević, B. \& Radičić, M. (2008), Public finance. Data Status, Belgrade. ISBN: 8674780903. [in Serbian: Раичевић, Б. \& Радичић, М. (2008), Јавне финансије]. 
14. Ristić, Ž. (2001). Fiscal management. Savremena administracija, Beograd. [in Serbian: Ристић, Ж. (2001), Фискални менаџмент].

15. Samjuelson, P.A. (1975). Economic reader. MATE, Zagreb. [in Serbian: Самјуелсон, П. А. (1975), Економска читанка].

16. Stiglic, J. (2013). Economic of Public Sector. Faculty of Economics, Belgrade. ISBN: 978-86-403-1291-2. [in Serbian: Штиглиц, J. (2013), Економија јавног сектора].

17. Cvjetković, C., Veselinović, J. \& Nikolić, I. (2015). Tax Treatment of Farmers in the Republic of Serbia, Economics of Agriculture, 62(3), 737-749, Belgrade. UDC: 336.226.4:63(497.11).

18. Individual Income Tax Law, „The Official Gazette of RS”, No. 24/01, 80/02 other law, 80/02, 135/04, 62/06, 65/06 - corrected, 31/09, 44/09, 18/10, 50/11, 91/11 - US, 93/12, 114/12 - US, 47/13, 48/13 - corrected, 108/13, 57/14, 68/14 - other law, 112/15; 113/17. [in Serbian: Закон о порезу на доходак грађана].

19. Law on value-added tax, "The Official Gazette of RS", No. 84/2004, 86/2004 - corrected., 61/2005, 61/2007, 93/2012, 108/2013, 6/2014 - adjusted amount in RSD, 68/2014 - other law, 142/2014, 5/2015 - adjusted amount in RSD, 83/2015, 5/2016 - adjusted amount in RSD, 108/2016 и 7/2017 - adjusted amount in RSD. [in Serbian: Закон о порезу на додату вредност].

20. Announcement regarding the taxation of registered agricultural holdings in 2014, Ministry of Finance - Tax Administration, Sector for Inspection, No. 000-430-02-0070/2013-Г0049 11.12.2013, Belgrade.

21. The Decision of the Ministry of Finance of the Republic of Serbia No. 413-00168/2013-04 as of 13.12.2013.

22. Regulation on the classification of activities, The Government of the Republic of Serbia - 05 No. 110-5482/2010. 